\title{
Quality characteristics of stored tomato fruit treated with two formulations of African black pepper
}

\section{Grace 0. Babarinde ${ }^{1}, *$, Gabriel 0. Adegoke $^{2}$, Rahman Akinoso ${ }^{2}$, R. Adekanye Bosede ${ }^{1}$}

\author{
${ }^{1}$ Food Science and Engineering Department. Ladoke Akintola University of \\ Technology. Ogbomoso. Nigeria. \\ ${ }^{2}$ Food Technology Department. University of Ibadan. Ibadan. Nigeria. ${ }^{*}$ E-mail: \\ gobabarinde@lautech.edu.ng.
}

\begin{abstract}
Tomato Solanum lycopersicum L. (Solanales: Solanaceae) is highly perishable and requires postharvest treatment to extend its shelf life. Use of synthetic chemicals to control post-harvest loss in tomato has adverse effect on health and there is need to explore natural alternatives to chemical. Two formulations of African black pepper Piper guineense Schumach. (Piperales: Piperaceae), aqueous extract and essential oil, were evaluated as preservatives for Roma type tomato fruit. Tomato fruits were treated with different concentrations of aqueous extracts and undiluted essential oil and stored under refrigeration condition. Samples were taken at 5-days interval and analyzed for weight loss, total soluble solids and ascorbic acid. Total Viable Count (TVC) and total mould count (TMC) were determined. Chemical composition of essential oil was identified using gas chromatography-mass spectrometer. Percent weight loss (PWL) in aqueous extract-treated tomato $(0.0 \%-0.68 \%)$ was lower than the control (0.3\%-19.97\%). The total soluble solid (brix) of samples in untreated fruit was lower than fruit treated with higher of $P$. guineense. Ascorbic acid contents were higher in aqueous extract-treated samples than the control. Essential oiltreated fruit had lower physiological weight loss TVC and TMC than the control. Twelve compounds were identified in P.guineense essential oil, the most of which were $\beta$-sesquiphellandrene $(23.7 \%)$. The $P$. guineense aqueous extract or essential oil is recommended as a bio-rational preservative for postharvest storage of tomato.
\end{abstract}

Keywords: Piper guineense; Tomato; Aqueous extract; Essential oil; Post-harvest storage.

Resumo. Características de qualidade de frutos de tomate armazenados tratados com duas formulações de pimenta preta africana. O tomate Solanum lycopersicum L. (Solanales: Solanaceae) é altamente perecível e requer tratamento pós-colheita para estender seu prazo de validade. O uso de substâncias químicas sintéticas para controlar a perda pós-colheita em tomate tem efeito
Received:

Mar. 14, 2018

Accepted:

26/04/2018

Released:

Apr. 30, 2018

Open access

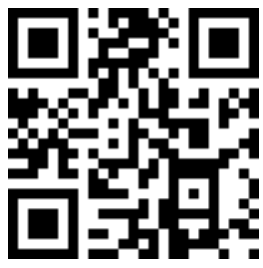

ORCID

(ㄱ) 0000-0002-3952-0316 Grace 0. Babarinde

(1) 0000-0003-1822-5876 Gabriel O. Adegoke

(D) 0000-0003-4783-7695 Rahman Akinoso

(D) 0000-0002-6273-0979

R. Adekanye Bosede 
adverso sobre a saúde e há necessidade de explorar alternativas naturais às substâncias químicas. Duas formulações de pimenta preta africana Piper guineens Schumach. (Piperales: Piperaceae), extrato aquoso e óleo essencial, foram avaliadas como conservantes para o fruto de tomate tipo Roma. Frutos de tomateiro foram tratados com diferentes concentrações de extratos aquosos e óleo essencial não diluído e armazenados sob refrigeração. As amostras foram coletadas no intervalo de cinco dias e analisadas para perda de peso, sólidos solúveis totais e ácido ascórbico. Contagem Total Viável (CTV) e contagem total de moldes (TMC) foram determinados. A composição química do óleo essencial foi identificada usando espectrômetro de massa por cromatografia gasosa. A perda percentual de peso (PPP) no tomate tratado com extrato aquoso $(0,0 \%-0,68 \%)$ foi menor do que no controle (0,3\%-19,97\%). O sólido solúvel total (brix) das amostras em frutos não tratados foi menor que os frutos tratados com maior teor de $P$. guineense. O conteúdo de ácido ascórbico foi maior em amostras tratadas com extrato aquoso do que o controle. Os frutos tratados com óleo essencial apresentaram menor perda de peso fisiológico, CTV e TMC do que o controle. Doze compostos foram identificados em óleo essencial de $P$. guineense, sendo a maior parte deles $\beta$-sesquipelenareno (23,7\%). Recomenda-se o extrato aquoso de $P$. guineense ou óleo essencial como conservante bio-racional para o armazenamento pós-colheita de tomate.

Palavras-chave: Piper guineense; Tomate; Extrato aquoso; Óleo essencial; Estocagem pós-colheita.

\section{Introduction}

Damage to vegetable quality in storage has been attributed to mechanical, physiological and microbial effects (Idah et al., 2007). Isack and Lyimo (2015) reported that postharvest handling practices affect qualitative and quantitative attributes of tomato. Some losses limit availability of crop to consumers and there is a need to extend shelf-life of crops. Extending shelf-life of climacteric fruit is important in tropical countries where production of vegetable is seasonal (Idah et al., 2012). If production continues and postharvest losses issues are not addressed there could be food and nutrition insecurity and increased poverty among smallholder farmers. Synthetic chemicals had been used over the years to extend shelf-life of fruits and vegetables, however, retention of residues of these chemical on food has become a major concern to consumers (Plotto et al.,
2003; Katalinic et al., 2013). Therefore, an alternative to the use of synthetic chemicals such as natural biodegradable compounds is necessary.

Spices and herbs have been reported to prolong shelf-life of foods due to their bacteriostatic and antioxidative activities (Jałosińska and Wilczak, 2009). Natural compounds are preferred by many consumers because they have reduced, or no mammalian toxicity, less environmental hazards, and wide public acceptability (Hassani et al., 2012). African black pepper Piper guineense Schumach. (Piperales: Piperaceae), is a spice that is widely consumed in Nigeria and Ghana due to its nutritional, antimicrobial and medicinal properties (Negbenebor et al., 1999). Okonkwo and Okoye (1996) investigated the efficacy of the crude extracts, essential oils and seed powders of $P$. guineense against the cowpea bruchid Callosobruchus maculates (Fabricius, 1775) (Coleoptera: Chrysomelidae). Its 
preservative potential in extending shelf life of fruits and vegetables can also be investigated due to its antimicrobial and antioxidant properties.

Tomato Solanum lycopersicum L. (Solanales: Solanaceae) is a climacteric fruit that is rich in vitamins and minerals (Nasrin et al., 2008). It is also an excellent source of lycopene (a very powerful antioxidant) that helps to prevent development of some cancers (Upangalawar et al., 2010). Tomato fruits outrank all other vegetables in total contribution to human nutrition because so much is consumed in so many different ways. It may be possible to reduce post-harvest loss in tomato using a biodegradable compound. Ahmed et al. (2017) reported that due to increase in fungicides residues on fruit and vegetables, there is therefore need for postharvest treatments of fruit and vegetables with natural products to reduce losses.

Hence, this study was designed to evaluate the preservative potentials of African black pepper on tomato fruit.

\section{Materials and methods}

Freshly harvested tomato fruits, cv. Roma VF, were obtained from a local farm in Iresaadu, Ogbomoso, Nigeria, sorted, cleaned and washed. African black pepper was procured from Bode Market, Ibadan, Nigeria.

\section{Preparation of $P$. guineense aqueous extract}

The dried seeds of $P$. guineense were cleaned and pulverized into fine powder using a hammer mill. Aqueous extracts $(1 \%, 2 \%, 3 \%, 4 \%$ and $5 \% \mathrm{w} / \mathrm{v})$ of these seeds were prepared. The solutions were kept in the refrigerator for 5 days followed by centrifugation as described by Adegoke et al. (2002).

\section{Extraction of essential oil}

Essential oil was extracted from $500 \mathrm{~g}$ pulverized $P$. guineense. The pre-weighed powder of $P$. guineense was added to $2 \mathrm{~L}$ water in $5 \mathrm{~L}$ capacity round bottom flask and essential oil was extracted using hydro-distillation with a Clevenger type apparatus.

\section{Treatment of tomato with aqueous extract and essential oil}

Tomato fruits were weighed into batches of $200 \mathrm{~g}$. Each batch was dipped separately into concentrations of $1 \%$, $2 \%, 3 \%, 4 \%$ and $5 \% \mathrm{w} / \mathrm{v}$ in water of $P$. guineense at the rate of $1000 \mathrm{~mL}$ spice extract per $200 \mathrm{~g}$ fruit for $20 \mathrm{~min}$. Another batch of $200 \mathrm{~g}$ was dipped into distilled water as the control. All samples were drained at ambient temperature $\left(26 \pm 2{ }^{\circ} \mathrm{C}\right)$ for $10 \mathrm{~min}$ according to Senevirathna and Daundasekera (2010). Extract-treated-fruits were placed in polyethylene packs which were sealed leaving 2.5-5 cm of head space in packs. Treated tomato fruits were stored at $5{ }^{\circ} \mathrm{C}$ for 30 days. Samples were removed at a 5-day-interval from each batch for analyses. The experiment was done in three replicates.

Freshly harvested tomato fruits were sorted to remove damaged ones. The fruits were rinsed in distilled water, drained and packaged in low density polyethylene (LDPE) bags. Cotton wool (approximately $0.5 \mathrm{~g}$ ) was attached to the inner tip of the LDPE bags and $10 \mu \mathrm{L}$ of the oil dispensed into the wool using a Hamilton ${ }^{\circledR}$ syringe so that the volatile oils could diffuse around tomato fruit without directly contacting them. Untreated samples were packaged using the same method but without essential oil. The LDPE bags were sealed with an electric sealer. Packaged samples were stored at $5{ }^{\circ} \mathrm{C}$ for 30 days. Samples were removed every 5 days for analyses.

\section{Physical analyses}

Physiological weight loss was determined by periodically weighing fruit and expressed as percent of original weight as described by Nasrin et al. (2008). 


\section{Chemical analyses}

Total soluble solids was determined using a refractometer (TechJam International Inc., Tokyo, Japan) and was expressed in terms of Brix (Akbudak and Akbudak, 2007). Ascorbic acid content in tomato pulp was determined according to Kirk and Sawyer (1991) using 2, 6, dichlorophenol indophenols visual titration.

\section{Total viable count}

The Petri dishes were in triplicate per dilution to be tested. The dishes were labeled appropriately. A portion $(0.2 \mathrm{~mL})$ of each dilution was pipette into the centre of appropriate dishes containing sterilized nutrient agar. The dishes were rotated in a clockwise and anticlockwise direction. The media were allowed to set, inverted and incubated at $27^{\circ} \mathrm{C}$ for $48 \mathrm{~h}$. Colonies were counted using an electronic counter (FISON Model CNW 330-010X) (Collins et al., 1989).

\section{Total mould count}

A portion $(0.2 \mathrm{~mL})$ of each dilution was dispensed into the centre of the appropriate plate containing potato dextrose agar. The plate was allowed to set, inverted and incubated at room temperature for $48 \mathrm{~h}$. All counts were carried out at regular intervals during fermentation period. Colonies were counted using the electronic counter (Collins et al., 1989).

\section{Identification of chemical compounds of essential oil}

The $P$. guineense essential oil was resolved in methanol. The resolved oil was injected into a GC-MS machine (GCMS-QP2010 Plus®, a product of Shimadzu, Kyoto, Japan), using an AOC20i auto sampler. The column used was Rtx-5MS (A product of Restek, USA) $(30 \mathrm{~m} \times 0.25 \mathrm{~mm}$ internal diameter $\mathrm{x}$ $0.25 \mu \mathrm{m}$ film thickness) coated with $5 \%$ diphenyl $95 \%$ dimethylpolysiloxane packing materials. The carrier gas was helium and a purge flow rate of $3 \mathrm{~mL} \cdot \mathrm{min}^{-1}$ and column flow rate
$0.99 \mathrm{~mL} \cdot \mathrm{min}^{-1}$. The GC was operated with the following conditions: oven temperature $60{ }^{\circ} \mathrm{C}$, for $2 \mathrm{~min}$, ramp of $10^{\circ} \mathrm{C} / \mathrm{min}$ up to $180{ }^{\circ} \mathrm{C}$ held for $3 \mathrm{~min}$, subsequent increase to $280{ }^{\circ} \mathrm{C}$ with a $15^{\circ} \mathrm{C} \cdot \mathrm{min}^{-1}$ heating ramp maintained at $280{ }^{\circ} \mathrm{C}$ for $3 \mathrm{~min}$. Injection temperature and volume were $250{ }^{\circ} \mathrm{C}$ and $1.0 \mu \mathrm{L}$, respectively. The MS operating conditions were ionization with an ion trap detector in full scan mode under electron impact ionization (EI) at $70 \mathrm{eV}$, ion source temperature $200^{\circ} \mathrm{C}$; interface temperature $250^{\circ} \mathrm{C}$, scan range, 40 $700 \mathrm{~m} \cdot \mathrm{z}^{-1}$. Identifications of components was based on comparison of the relative Kovets Retention Index (RI) using a hydrocarbon homologous. The relative concentrations of components $(\%$ composition) were obtained by peak areas (Rtx-5MS column). They were estimated by dividing the area of each component by the total area of all components isolated under MS (Maggi et al., 2009).

\section{Statistical analysis}

Data of extract bioassays were analyzed by analysis of variance (ANOVA) using SPSS (2006). The Duncan multiple range test was used to separate differences among means. For essential oil bioassay, data were subjected to studentized t-test.

\section{Results and discussion}

\section{Aqueous treated samples}

Physical Properties. Treatment

with extracts of $P$. guineense reduced percent weight loss compared to the control (Table 1). Percent weight loss increased as storage time progressed. There was no weight loss for 5\% treated samples at day 5 but significant weight loss was observed at day 20; significantly higher losses occurred in the control. Higher concentrations of $4 \%-5 \% \quad P$. guineense extract had the lowest percent weight loss at the end of storage. Weight loss can be attributed to respiration rate because a carbon atom is lost from the 
fruit each time a carbon-dioxide molecule is produced (Bhowmilk and Pan, 1992). Sammi and Masud (2007) treated tomato with calcium chloride, boric acid and potassium permanganate and reported significant reduction in weight of treated fruit. Reduction in weight loss could be attributed to some constituents of $P$. guineense extract leading to reduced respiration rate. Sudha et al. (2007) postulated that reduction of weight loss of tomato treated with gibberellic acid could be due to its anti-senescent action.

Table 1 Percent weight loss of P. guineense aqueous treated tomato fruit during refrigerated storage.

\begin{tabular}{ccccccc}
\hline $\begin{array}{c}\text { Piper guineense } \\
\text { extract } \\
(\mathbf{\%}, \mathbf{w} / \mathbf{v})\end{array}$ & $\mathbf{5}$ & $\mathbf{1 0}$ & $\mathbf{1 5}$ & $\mathbf{2 0}$ & $\mathbf{2 5}$ & $\mathbf{3 0}$ \\
\cline { 2 - 7 } & $0.02 \pm 0.01^{\mathrm{a}}$ & $0.07 \pm 0.01^{\mathrm{b}}$ & $0.18 \pm 0.01^{\mathrm{b}}$ & $0.30 \pm 0.00^{\mathrm{b}}$ & $0.41 \pm 0.01^{\mathrm{b}}$ & $0.68 \pm 0.04^{\mathrm{b}}$ \\
2 & $0.01 \pm 0.00^{\mathrm{a}}$ & $0.02 \pm 0.00^{\mathrm{b}}$ & $0.13 \pm 0.01^{\mathrm{b}}$ & $0.35 \pm 0.00^{\mathrm{b}}$ & $0.44 \pm 0.01^{\mathrm{b}}$ & $0.50 \pm 0.01^{\mathrm{c}}$ \\
3 & $0.02 \pm 0.01^{\mathrm{a}}$ & $0.02 \pm 0.00^{\mathrm{b}}$ & $0.12 \pm 0.01^{\mathrm{b}}$ & $0.33 \pm 0.03^{\mathrm{b}}$ & $0.42 \pm 0.02^{\mathrm{b}}$ & $0.49 \pm 0.01^{\mathrm{c}}$ \\
4 & $0.03 \pm 0.01^{\mathrm{a}}$ & $0.04 \pm 0.00^{\mathrm{b}}$ & $0.14 \pm 0.03^{\mathrm{b}}$ & $0.31 \pm 0.01^{\mathrm{b}}$ & $0.37 \pm 0.01^{\mathrm{b}}$ & $0.49 \pm 0.01^{\mathrm{c}}$ \\
5 & $0.00 \pm 0.00^{\mathrm{a}}$ & $0.02 \pm 0.00^{\mathrm{b}}$ & $0.13 \pm 0.03^{\mathrm{b}}$ & $0.29 \pm 0.01^{\mathrm{b}}$ & $0.34 \pm 0.01^{\mathrm{b}}$ & $0.43 \pm 0.01^{\mathrm{c}}$ \\
Control & $0.09 \pm 0.01^{\mathrm{a}}$ & $0.27 \pm 0.05^{\mathrm{a}}$ & $0.55 \pm 0.11^{\mathrm{a}}$ & $3.45 \pm 0.12^{\mathrm{a}}$ & $18.23 \pm 1.87^{\mathrm{a}}$ & $19.97 \pm 1.37^{\mathrm{a}}$ \\
\hline
\end{tabular}

aValues in columns followed by the same letter are not significantly different $(\mathrm{P}>0.05)$.

Chemical Properties. Total soluble solid (TSS) of fresh fruit decreased (Table 2) as storage progressed. Initial reduction in TSS of samples treated with $P$. guineense was observed in the first 25 days. The increase in TSS could be due to transformation of pectin substances and other polysaccharides into soluble sugar (Mounika et al., 2017). At the end of the storage, samples treated with $4 \%$ and $5 \%$. guineense had the highest brix values.

Table 2 Influence of $P$. guineense aqueous extracts on total soluble solids (brix) of tomato during refrigerated storage.

\begin{tabular}{cccccccc}
\hline $\begin{array}{c}\text { Piper guineense } \\
\text { extract } \\
(\%, \mathbf{w} / \mathbf{v})\end{array}$ & $\mathbf{0}$ & $\mathbf{5}$ & $\mathbf{1 0}$ & $\mathbf{1 5}$ & $\mathbf{2 0}$ & $\mathbf{2 5}$ & $\mathbf{3 0}$ \\
\cline { 2 - 8 } & & & & & \multicolumn{2}{c}{ Storage period (days) } \\
2 & $3.37 \pm 0.06^{\mathrm{a}}$ & $2.03 \pm 0.06^{\mathrm{c}}$ & $1.73 \pm 0.06^{\mathrm{c}}$ & $1.20 \pm 0.06^{\mathrm{c}}$ & $1.00 \pm 0.00^{\mathrm{c}}$ & $1.00 \pm 0.00^{\mathrm{b}}$ & $1.27 \pm 0.06^{\mathrm{b}}$ \\
3 & $3.37 \pm 0.06^{\mathrm{a}}$ & $2.33 \pm 0.06^{\mathrm{b}}$ & $1.83 \pm 0.06^{\mathrm{b}}$ & $1.37 \pm 0.06^{\mathrm{b}}$ & $1.07 \pm 0.06^{\mathrm{b}}$ & $1.03 \pm 0.06^{\mathrm{b}}$ & $1.40 \pm 0.10^{\mathrm{a}}$ \\
4 & $3.37 \pm 0.06^{\mathrm{a}}$ & $2.47 \pm 0.06^{\mathrm{b}}$ & $1.93 \pm 0.01^{\mathrm{b}}$ & $1.43 \pm 0.06^{\mathrm{a}}$ & $1.10 \pm 0.06^{\mathrm{b}}$ & $1.07 \pm 0.06^{\mathrm{b}}$ & $1.53 \pm 0.06^{\mathrm{a}}$ \\
5 & $3.37 \pm 0.06^{\mathrm{a}}$ & $2.93 \pm 0.06^{\mathrm{a}}$ & $2.13 \pm 0.06^{\mathrm{a}}$ & $1.47 \pm 0.06^{\mathrm{a}}$ & $1.17 \pm 0.06^{\mathrm{b}}$ & $1.07 \pm 0.06^{\mathrm{b}}$ & $1.67 \pm 0.06^{\mathrm{a}}$ \\
\hline & $2.47 \pm 0.06^{\mathrm{a}}$ & $1.47 \pm 0.04^{\mathrm{a}}$ & $1.23 \pm 0.06^{\mathrm{a}}$ & $1.17 \pm 0.06^{\mathrm{a}}$ & $1.80 \pm 0.00^{\mathrm{a}}$ \\
Control & $3.37 \pm 0.06^{\mathrm{a}}$ & $2.30 \pm 0.01^{\mathrm{b}}$ & $1.70 \pm 0.10^{\mathrm{c}}$ & $1.30 \pm 0.00^{\mathrm{b}}$ & $1.17 \pm 0.06^{\mathrm{b}}$ & $1.07 \pm 0.06^{\mathrm{b}}$ & $1.00 \pm 0.00^{\mathrm{b}}$ \\
\hline
\end{tabular}

Means with similar letters along the column are not significantly $(\mathrm{P}>0.05)$ different.

Ascorbic acid was lower in untreated samples on day 5 (Table 3). Ascorbic acid was further reduced on day
15 of storage and the control samples had the lowest values. Ascorbic acid was best retained in samples treated with 
4\%-5\% P. guineense. At the end of storage, samples treated with $4 \%$ P.guineense had the highest values. Babarinde and Adegoke (2015) reported antioxidative effect of Xylopia aethiopica (Dunal) A. Rich. (Magnoliales: Annonaceae) when tomato was treated with aqueous extract of $X$. aethiopica. Better retention of ascorbic acid in P.guineense treated samples confirmed the antioxidative properties of the material (Adegoke and GopalaKrishna, 1998; Besong et al., 2016). The ascorbic acid content of tomato as reported by Akbudak and Akbudak (2007) was $28.1 \mathrm{mg} / 100 \mathrm{~g}$ which is higher than the value reported in this study. The reason for the variation could be due to varietal differences and maturity stage (Leonardi et al., 2000). Renhua et al. (2008) reported that exogenous pre-treatment of vegetables could change the antioxidant system and maintain their nutritional value. This treatment could be responsible for maximum ascorbic acid in P.guineense treated samples.

Table 3 Ascorbic acid contents (mg/100 g) of tomato treated with P. guineense aqueous extract during refrigerated storage.

\begin{tabular}{lccccccc}
\hline $\begin{array}{c}\text { P. guineense } \\
\text { extract } \\
(\%, \mathbf{w} / \mathbf{v})\end{array}$ & $\mathbf{0}$ & $\mathbf{5}$ & $\mathbf{1 0}$ & $\mathbf{1 5}$ & $\mathbf{2 0}$ & $\mathbf{2 5}$ & $\mathbf{3 0}$ \\
\cline { 2 - 8 } & $22.00 \pm 0.00^{\mathrm{a}}$ & $19.27 \pm 0.23^{\mathrm{b}}$ & $16.13 \pm 0.12^{\mathrm{c}}$ & $13.63 \pm 0.12^{\mathrm{b}}$ & $13.63 \pm 0.12^{\mathrm{b}}$ & $10.70 \pm 0.10^{\mathrm{c}}$ & $11.30 \pm 0.10^{\mathrm{b}}$ \\
1 & $22.00 \pm 0.00^{\mathrm{a}}$ & $20.10 \pm 0.23^{\mathrm{b}}$ & $17.10 \pm 0.12^{\mathrm{b}}$ & $14.43 \pm 0.12^{\mathrm{b}}$ & $14.43 \pm 0.12^{\mathrm{b}}$ & $12.03 \pm 0.06^{\mathrm{b}}$ & $11.96 \pm 0.06^{\mathrm{a}}$ \\
2 & $22.00 \pm 0.00^{\mathrm{a}}$ & $20.77 \pm 0.17^{\mathrm{a}}$ & $17.77 \pm 0.06^{\mathrm{a}}$ & $15.20 \pm 0.00^{\mathrm{a}}$ & $15.20 \pm 0.00^{\mathrm{a}}$ & $12.67 \pm 0.06^{\mathrm{a}}$ & $12.67 \pm 0.06^{\mathrm{a}}$ \\
3 & $22.00 \pm 0.00^{\mathrm{a}}$ & $21.10 \pm 0.10^{\mathrm{a}}$ & $18.53 \pm 0.10^{\mathrm{a}}$ & $15.37 \pm 0.06^{\mathrm{a}}$ & $15.37 \pm 0.06^{\mathrm{a}}$ & $13.17 \pm 0.06^{\mathrm{a}}$ & $13.03 \pm 0.06^{\mathrm{a}}$ \\
4 & $22.00 \pm 0.00^{\mathrm{a}}$ & $21.80 \pm 0.06^{\mathrm{a}}$ & $18.53 \pm 0.06^{\mathrm{a}}$ & $15.53 \pm 0.06^{\mathrm{a}}$ & $15.53 \pm 0.06^{\mathrm{a}}$ & $13.63 \pm 0.06^{\mathrm{a}}$ & $12.23 \pm 0.06^{\mathrm{a}}$ \\
5 & $22.00 \pm 0.00^{\mathrm{a}}$ & $18.17 \pm 0.29^{\mathrm{c}}$ & $17.27 \pm 0.06^{\mathrm{b}}$ & $12.10 \pm 0.10^{\mathrm{c}}$ & $11.20 \pm 0.17^{\mathrm{c}}$ & $10.40 \pm 0.10^{\mathrm{c}}$ & $10.07 \pm 0.06^{\mathrm{c}}$ \\
\hline Control & & &
\end{tabular}

Means with similar letters along the column are not significantly $(\mathrm{P}>0.05)$ different.

\section{Essential oil treated samples}

Percentage weight loss of samples treated with essential oil of P. guineense was lower than the control (Figure 1). Loss in weight progressively increased with storage period. When tomato fruit were refrigerated for 30 days, oil-treated samples had less weight loss than the untreated control. Hassani et al. (2012) reported the potential of essential oils in weight loss reduction could be attributed to the oily characteristics which covers the fruit surface and reduces respiration.

Effect of essential oil of $P$.guineense on microbial load of tomato fruits during storage

The results obtained for total viable count and total mould count are shown in Figures 2 and 3. The essential oil of P.guineense demonstrated antimicrobial property. The dosage of $10 \mu \mathrm{L}$ of essential oil of $P$. guineense per
$200 \mathrm{~g}$ tomato fruits significantly $(\mathrm{P}<0.05)$ inhibited the growth of microorganism. Lowest counts were recorded in day 25. The role of monoterpenes in disturbing the membrane functions of yeasts has been reported by Adegoke et al. (2000) and synergistic effects of essential oil components were established (Parveen et al., 2004).

Abd Alla et al. (2008) reported that cinnamaldehyde vapour used in the packaging of apricot reduced fungal rot on inoculated fruits. Their observation supports the results obtained in this study as the colony forming ability of mould was reduced during storage of tomato fruits. Krisch et al. (2011) observed that essential oils can be used to prolong shelf life of fruits in vapour phase in active packaging or as coating on the surfaces of fruits. 


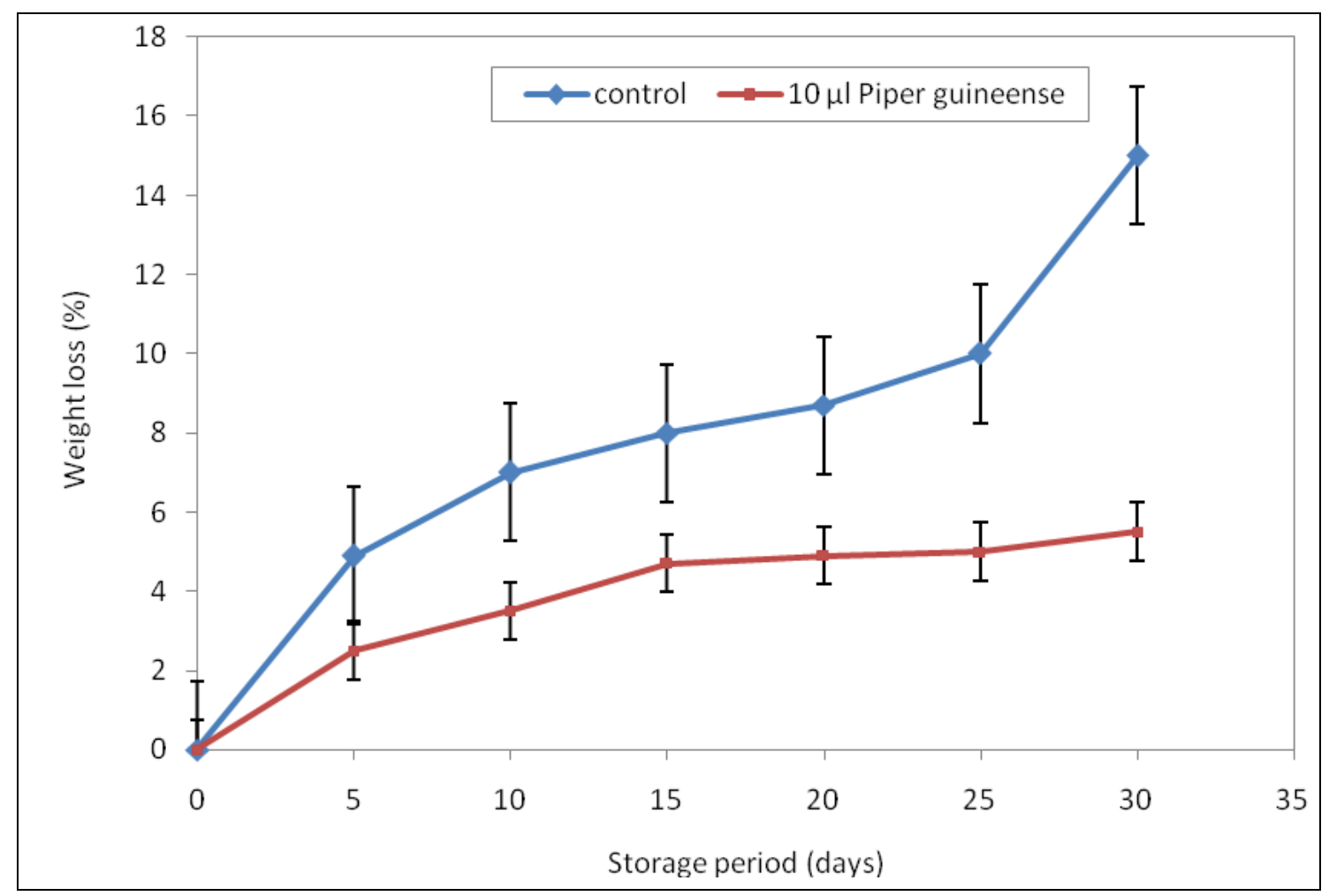

Figure 1. Weight loss of tomato fruits treated with essential oil of $P$. guineense stored at refrigeration condition.

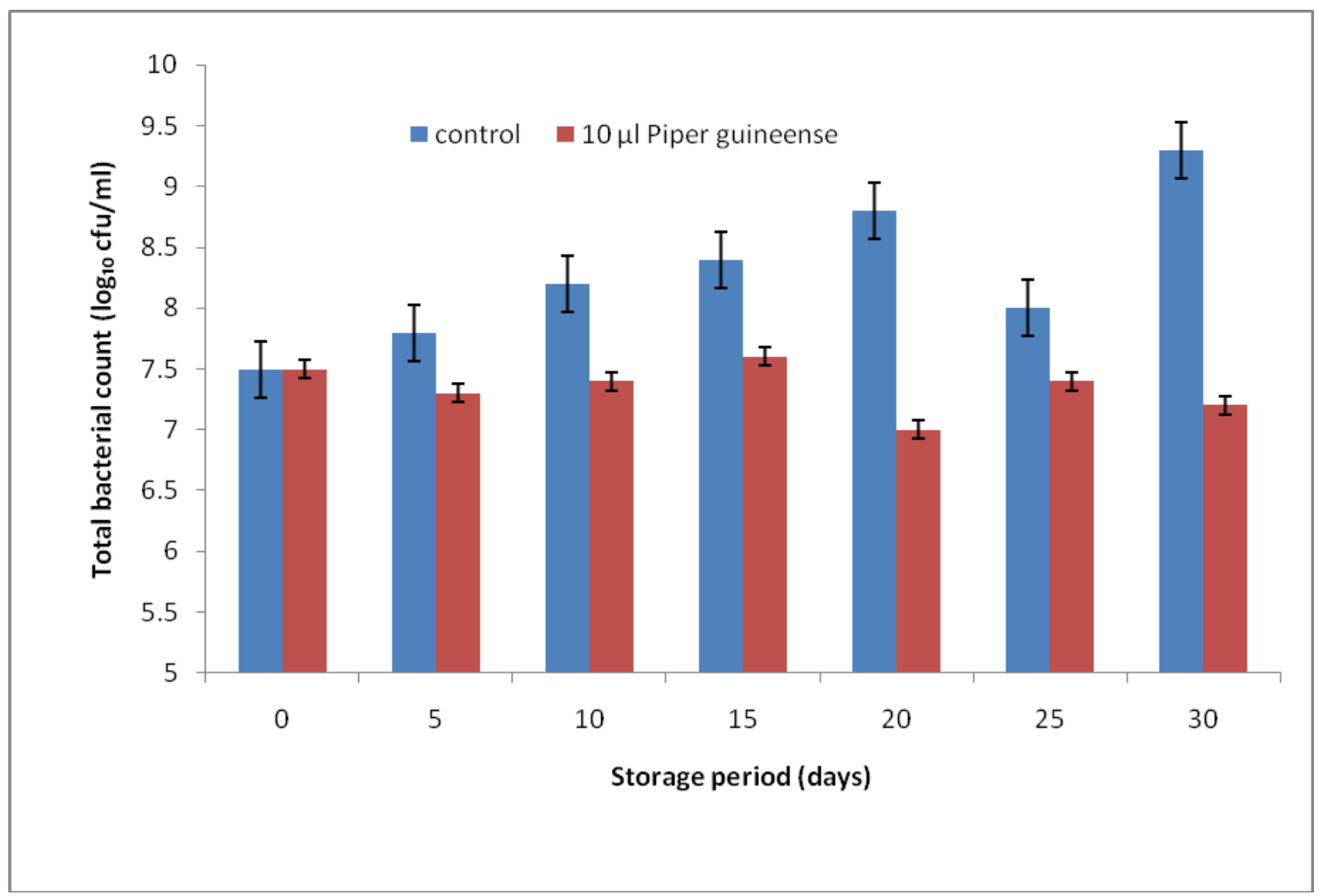

Figure 2. Total bacterial counts of tomato fruits treated with essential oil of Piper guineense stored at refrigeration condition. 


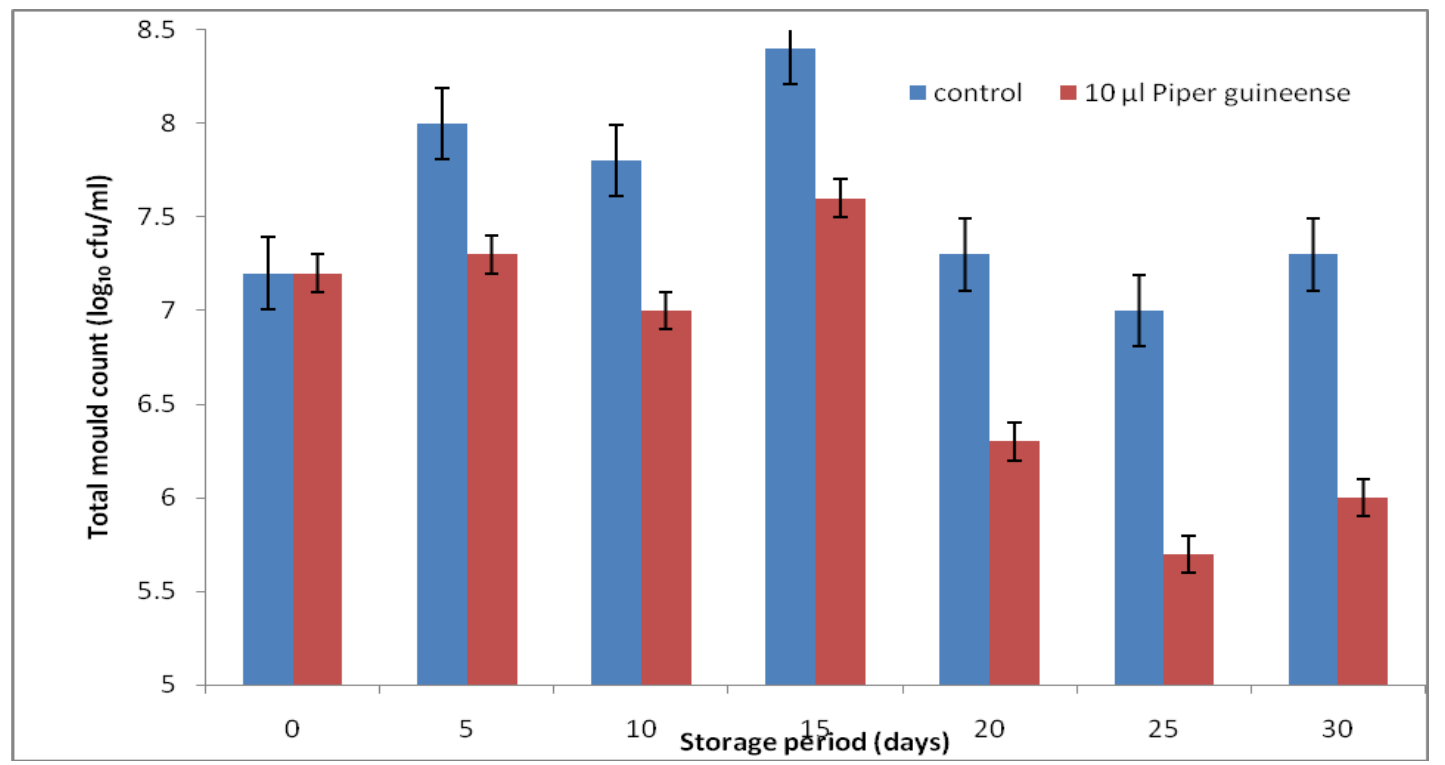

Figure 3. Total mould count of tomato fruits treated with essential oil of Piper guineense stored at refrigeration condition.

\section{Chemical composition of the essential oil of $P$. guineense}

Twelve chemical components were identified in $P$. guineense essential oil (Table 4). Sesquiterpene hydrocarbons were predominant, followed by oxygenated monoterpenes and monoterpene hydrocarbons. The most abundant constituents of $P$. guineense were $\beta$-sesquiphellandrene, 1,5-heptadiene, $\beta$-bisabolene, 6-methyl2-(4-methyl-3-cyclohexene-1-yl), $\quad \beta$ - caryophyllene, linalool, zingiberene, $\beta$ farnesene and Guaia-1(5), 11-diene. Minor constituents were $\beta$-pinene, limonene, 2, 4 diisopropenyl-1-methyl-1vinylcyclohexane, $\alpha$-cubebene and $\alpha$ caryophyllene. Martins et al. (1998) analyzed the essential oil of $P$. guineense and reported that the oil was characterized with $20.5 \%$ monoterpenes, $5.5 \%$ oxygenated monoterpenes, $11.6 \%$ sesquiterpenes and $2.1 \%$ oxygenated sesquiterpene.

Table 4. Chemical composition of the essential oil of $P$. guineense.

\begin{tabular}{clrr}
\hline & \multicolumn{1}{c}{ Component $^{\mathbf{a}}$} & RI $^{\mathbf{b}}$ & \% compositionc $^{\mathbf{c}}$ \\
\hline 1 & Beta-pinene & 943 & 1.52 \\
2 & Limonene & 1018 & 1.73 \\
3 & Linalool & 1082 & 10.70 \\
4 & Alpha-cubebene & 1344 & 1.75 \\
5 & 2, 4 diisopropenyl-1-methyl-1-vinylcyclohexane & 1398 & 3.36 \\
6 & Beta caryophyllene & 1494 & 12.63 \\
7 & Beta farnesene & 1440 & 8.13 \\
8 & Alpha caryophyllene & 1579 & 3.18 \\
9 & Guaia-1(5), 11-diene & 1490 & 6.91 \\
10 & Zingiberene & 1451 & 9.98 \\
11 & 1,5-heptadiene, 6-methyl-2-(4-methyl-3-cyclohexene-1-yl) & 1500 & 16.37 \\
12 & Beta sesquiphellandrene & 1446 & 23.74 \\
\hline
\end{tabular}

aComponents identified by comparing MS, with NIST (2005) library spectra software.

bKovats retention indices relative to n-alkanes (C8-C22) on fused silica capillary column Rtx 5MS. c\% peak area relative to total peak area obtained from TIC total peak report. 
Phenyl propanoid derivatives were the most important group of components in the oil of $P$. guineense identified with dillapiole (44.8\%) being the main constituent, followed by myristicin (9.8\%). Jirovetz et al. (2002) reported that the essential oil of $P$. guineense contained (black)- $\beta$ caryophyllene $\quad(57.59 \%), \quad \beta$-elemene (5.10\%), bicyclogermacrene $(5.05 \%)$ and $\alpha$-humulene (4.86\%); and P. guineense (white)- $\beta$-caryophyllene (51.75\%), cis-bocimene $(6.61 \%)$, limonene $(5.88 \%), \beta$ pinene $(4.56 \%)$, linalool $(3.97 \%)$ and $\alpha-$ humulene (3.29\%).

\section{Conclusion}

Postharvest treatment of tomato fruits with $P$. guineense extracts reduced weight loss, inhibited growth of micro organism and retained ascorbic acid better than the untreated sample. The essential oil of $P$. guineense possesses preservative properties and can be used in post-harvest storage of tomato.

\section{Conflict of Interest} interest.

The authors declare no conflict of

\section{References}

Abd Alla, M. A.; El-Sayed, H. Z.; Riad, S. E. Control of rhizopus rot disease of apricot fruits (Prunus armeniaca) by some plants volatiles aldehydes. Research Journal of Agriculture and Biological Sciences, v. 4, no. 5, p. 424-433, 2008. Available from: <http://www.aensiweb.net/AENSIWEB/rjab s/rjabs/2008/424-433.pdf>. Accessed on: Dec. 22, 2017.

Adegoke G. O.; Iwahashi H.; Komatsu Y.; Obuchi, K.; Iwahashi, Y. Inhibition of food spoilage yeasts and aflatoxigenic moulds by monoterpenes of the spice Aframomum danielli. Flavour and Fragrance Journal, v. 15 , p. 147-150, 2000. https://doi.org/ 10.1002/1099-1026(200005/06)15:3<147:: AID-FFJ883>3.0.CO;2-0

Adegoke, G. O.; Fasoyiro, S. B.; Skura, B. Control of microbial growth, browning and lipid oxidation by the spice; Aframomum danielli. European Food Research Technology, v. 211, p. 342-345, 2002. https://doi.org/10.1007/s002170000170

Adegoke, G. O.; Gopala Krishna, A. G. Extraction and identification of antioxidants from the spice Aframomum danielli, Journal of American Oil Chemical Society, v. 75, p. 1047-1052, 1998. https://doi.org/10.1007/ s11746-998-0285-3

Ahmed, F. A.; Sipes, B. S.; Alvarez, A. M. Postharvest diseases of tomato and natural products for disease managements. African Journal of Agricultural Research, v. 12, p. 684-691, 2017. https://doi.org/10.5897/ AJAR2017.12139

Akbudak, B.; Akbudak, N. Effects of hot water treatment and modified atmosphere packaging on the quality and cold storage life of cherry tomatoes. Journal of Food Science and Technology, v. 44 , no. 2, p. 216-219, 2007.

Babarinde, G. O.; Adegoke, G. O. Effect of Xylopia aethiopica aqueous extract on antioxidant properties of refrigerated Roma tomato variety packaged in low density polyethylene bags. Journal of Food Science and Technology, v. 52, no. 3, p. 1790-1795, 2015. https://doi.org/10.1007/s13197-0131157-x

Besong, E. E.; Balogun, M. E.; Djobissie, S. F. A.; Ogochukwu, S.; Mbamalu, O. S.; Obimma, J. N. A. Review of Piper guineense (African black pepper). International Journal of Pharmacy and Pharmaceutical Research, v. 6, no. 1, p. 368-384, 2016. Available from: <http://ijppr.humanjournals.com/wpcontent/uploads/2016/05/34.Elizabeth-E.Besong-Morufu-E.-Balogun-Serges-F.-A.Djobissie-Ogochukwu-S.-Mbamalu-JacintaN.Obimma.pdf>. Accessed on: Dec. 22, 2017.

Bhowmilk, S. R.; Pan, J. C. Shelf life of mature green tomatoes stored in controlled atmosphere and high humidity. Journal of Food Science, v. 57, p. 948-953, 1992. https://doi.org/10.1111/j.1365-2621.1992. tb14331.x

Collins, C. H.; Lyne, M.; Grage, J. M. Microbiological methods. 6. ed. London: Butter North, 1989.

Hassani, A.; Fathi, Z.; Ghosta, Y.; Abdollahi, A.; Meshkatalsadat, M. H.; Marandi, R. J. Evaluation of plant essential oils for control of postharvest brown and gray mold rots on apricot. Journal of Food Safety, v. 32, p. 94- 
101, 2012. https://doi.org/10.1111/j.17454565.2011.00353.x

Idah, P. A.; Ajisegiri, E. S. A.; Yisa, M. G. Fruits and vegetables handling and transportation in Nigeria. AU Journal of Technology, v. 10, no. 3, p. 175-183, 2007. Available from: <http://www.journal.au.edu/au_techno/200 7/jan07/vol10no3_article6.pdf >. Accessed on: Dec. 22, 2017.

Idah, P. A.; Yisa, M. G.; Chukwu O.; Morenikeji, O. O. Simulated transport damage study on fresh tomato (Lycopersicon esculentum) fruits. Agricultural Engneering International, CIGR Journal, v. 14, no. 2, p.1-14, 2012. Available from: <http://www.cigrjournal.org/index.php/Ejo unral/article/view/2035/1595>. Accessed on: Dec. 22, 2017.

Isack, M. E.; Lyimo, M. Effect of postharvest handling practices on physicochemical composition of tomato. International Journal of Vegetable Science, v. 21 no. 2, p. 118-127, 2015. https://doi.org/10.1080/ 19315260.2013.837134

Jałosińska, M.; Wilczak, J. Influence of plant extracts on the microbiological shelf life of meat products. Polish Journal of Food Nutrition and Science, v. 59 , no. 4, p. 303308, 2009. Available from: <http://journal.pan.olsztyn.pl/pdfy/2009/4/ 4.pdf>. Accessed on: Dec. 22, 2017.

Jirovetz, G.; Buchbauer, B.; Ngassoum, M. B.; Geissler, M. Aroma compound analysis of Piper nigrum and Piper guineense essential oils from Cameroon using solid-phase micro extraction-gas chromatography, solid-phase micro extraction-gas chromatography-mass spectrometry and olfactometry. Journal of Chromatography, v. 976 , no. $1 / 2$, p. 265 275, 2002. https://doi.org/10.1016/S00219673(02)00376-X

Katalinic, V.; Mozina, S. S.; Generalic, I.; Skroza, D.; Ljubenkov, I.; Klancnik, A. Phenolic profile, antioxidant capacity and antimicrobial activity of leaf extracts from six Vitis vinifera $\mathrm{L}$. varieties International Journal of Food Properties, v. 16, no. 1, p. 45-60, 2013. https://doi.org/10.1080/ 10942912.2010.526274

Kirk, R. S.; Sawyer R. Pearson's composition and analysis of foods. 9. ed. London: Longman Scientific and Technical, 1991.

Krisch J.; Tserennadmid R.; Vágvölgyi C. Essential oils against yeasts and moulds causing food spoilage. In: Vilas, A. M. (Ed.).
Science against microbial pathogens: communicating current research and technological advances. Badajoz, Spain: Formatex Research Center, 2011. p. 1-8.

Leonardi, C.; Ambrosino, P.; Esposito, F.; Fogliano, V. Antioxidants activity and carotenoid and tomatine contents in different typologies of fresh consumption tomatoes. Journal of Agriculture and Food Chemistry, v. 48, p. 4723-4727, 2000. https://doi.org/10.1021/jf000225t

Maggi, F.; Cecchini, C.; Cresci, A.; Coman, M. M.; Tirillini, B.; Sagratini, G.; Papa, F. Chemical composition and antimicrobial activity of the essential oil from Ferula glance L. (F. communis L. subsp. glanca) growing in Marche (Central Italy). Fitoterapia, v. 80, p. 68-72, 2009. https://doi.org/10.1016/ j.fitote.2008.10.001

Martins, A. P.; Salgueiro, L.; Vila, R.; Tomi, F.; Caniguerai, S.; Casanova, J.; Proença da Cunha, A.; Adzet, T. Essential oils from four Piper species. Phytochemistry, v. 49, no. 7, p. 2019-2023, 1998. https://doi.org/10.1016/ S0031-9422(98)00391-4

Mounika, T.; Reddy, N. N.; Lakshmi, N. J.; Joshi, V. Studies on the effect of post harvest treatments on shelf life and quality of mango [Mangifera indica L.] cv. Amrapali. Journal of Applied and Natural Science, v. 9, no. 4, p. 2055-2061, 2017. Available from: <https://journals.ansfoundation.org/index.p hp/jans/article/view/1488/1425>. Accessed on: Dec. 22, 2017.

Nasrin, T. A. A.; Molla, M. A.; Hossaen, M. A.; Alam, M. S.; Yasmin L. Effect of postharvest treatments on shelf life and quality of tomato. Bangladesh Journal of Agricultural Research, v. 33, p. 579-585, 2008. https://doi.org/10.3329/bjar.v33i4.2291

Negbenebor, C. A.; Godiya, A. A.; Igene, J. 0. Evaluation of Clarias anguillains treated with spice (Piper guineense) for washed mice and kama book type product. Journal of Food Composition and Analysis, v. 12 , no. 4, p. 312-315. 1999. https://doi.org/10.1006/ jfca.1999.0824

Okonkwo, E. U.; Okoye, W. I. The efficacy of four seed powders and the essential oils as protectants of cowpea and maize grains against infestation by Callosobruchus maculatus (Fabricus) (Coleoptera: Bruchidae) and Sitophilus zeamais (Motschulsky) (Coleoptera: Curculionidae) in Nigeria. International Journal of Pest 
Management, v. 42, no. 2, p. 143-146, 1996. https://doi.org/10.1080/09670879609371985

Parveen, M.; Hassan, K.; Tkahashi, J.; Murata, Y.; Kitagawa E.; Kodama, O.; Iwahas, $\mathrm{H}$. Response of Saccharomyces cerevisiae to a monoterpene: evaluation of antifungal potential by DNA microarray analysis. Journal of Antimicrobial Chemotherapy, v. 54 , p. $46-55,2004$. https://doi.org/ 10.1093/jac/dkh245

Pila, N.; Gol, N. B.; Rao, T. V. R. Effect of postharvest treatments on physicochemical characteristics and shelf life of tomato (Lycopersicon esculentum Mill) fruits during storage. American-Eurasian Journal of Agriculture Environmental Science, v. 9, no. 5, p. 470-479, 2010. Available from: <http://idosi.org/aejaes/jaes9(5)/3.pdf>. Accessed on: Dec. 22, 2017.

Plotto, A.; Roberts, R. G.; Roberts, D. D. Evaluation of plant essential oils as natural post harvest disease control of tomato (Lycopersicon esculentum). Acta Horticulturae, v. 628, p. 737-745, 2003. https://doi.org/10.17660/ActaHortic.2003.6 28.93

Renhua, H.; Renxue, X.; Yunmel, L.; Liming, H.; Yongjie, X. Effect of pre-harvest salicylic acid spray treatment on postharvest antioxidant in the pulp and peel of 'Cara cara' navel orange. (Citrus sinenisis L. Osbeck). Journal of Science of Food and Agriculture, v. 8, p. 229-236, 2008. https://doi.org/10.1002/ jsfa.3076

Sammi, S.; Masud, T. Effect of different packaging systems on storage life and quality of tomato (Lycopersicon esculentum var. Rio Grande) during different ripening stages. International Journal of Food Safety, v. 9, p. 37-44, 2007. https://doi.org/10.1111/ j.1365-2621.2007.01649

Sancho, L. E.; Gayosso-García, Y.; Elhadi, M.; Martínez-Téllez, M. A.; González-Aguilar, G. A. Effect of maturity stage of papaya maradol on physiological and biochemical parameters. American Journal of Agriculture and Biological Science, v. 5, p. 194-203, 2010. https://doi.org/10.3844/ajabssp.2010.194.203

Senevirathna, P; Daundasekera, W. Effect of postharvest calcium chloride vacuum infiltration on the shelf life and quality of Tomato (cv. 'thilina'). Ceyian Journal of Science (Biological Science), v. 39, no. 1, p. 35-44, 2010. https://doi.org/10.4038/cjsbs. v39i1.2351

SPSS - Statistical Package for Social Sciences. version 15.0 for windows. SPSS Inc., Chicago, IL. 2006.

Sudha, R.; Amutha, R.; Muthulaksmi, S.; Baby Rani, W.; Indira, K.; Mareeswari, P. Influence of pre and postharvest chemical treatments on physical characteristics of sapota (Achras sapota L.) var. PKM 1. Research Journal of Agriculture and Biological Sciences, v. 3, no. 5, p. 450-452, 2007. Available from: <http://www.aensiweb.net/AENSIWEB/rjab s/rjabs/2007/450-452.pdf>. Accessed on: Dec. 22, 2017.

Upaganlawar, A.; Gandhi, H.; Balaraman, J. Effect of vitamin $\mathrm{E}$ alone and in combination with lycopene on biochemical and histopathological alterations in isoproterenol-induced myocardial infarction in rats. Journal of Pharmacology \& Pharmacotherapy, v. 1, p. 24-31, 2010. https://doi.org/10.4103/0976-500X. 64532 